Ewa Krychniak

\title{
Kultura książki w regionie sokólskim
}

\section{Dzieje regionu i miasta Sokółki}

7 Peren obecnego regionu sokólskiego w odległych czasach zamieszkiwali przez kilka wieków Jadżwingowie. Pierwsze wieki ich hi-

\ storii są pokryte mrokiem. Dopiero kronikarze: Jan Długosz i Maciej Stryjkowski' opisują ich dzieje, począwszy od końca X wieku.

Okres zaboru rosyjskiego pozostawia po sobie najgorszą pamięć. Kierując się względami narodowościowymi i religijnymi rząd rosyjski nie dba o rozwój gospodarczy i kulturalny regionu sokolskiego. Prowadzono usilną rusyfikację regionu.

Na terenie regionu sokolskiego nie brakowało odgłosów powstań i wojen. Udział mieszkańców w wojnie polsko-bolszewickiej (1920 r.) i znaczna liczba poległych $\mathrm{z}$ regionu tak usilnie rusyfikowanego przez zaborcę, daje najlepsze świadectwo patriotyzmu tej ludności i poświęcenie jej dla Polski. Okres okupacji niemieckiej (1939-1945) wycisnął też swoje piętno na ludności. Ofiary hitleryzmu przebywały w łagrach niemieckich, zaś w latach okupacji sowieckiej były zsyłki na Syberię.

W roku 1589 Zygmunt II Waza nadał Sokółce prawa targowe, a do godności miasta podniesiona została przywilejem królewskim 28 marca $1609 \mathrm{r}^{2}$ Miasto otrzymało herb - w górnym polu tarczy tur, u dołu popiersie rycerza z obnażonym mieczem.

Za panowania Jana III Sobieskiego w okolicy Sokółki rozwinęło się osadnictwo tatarskie. W roku 1679 król osiedlił Tatarów na pustych włókach niektórych wsi ekonomii grodzieńskiej. Byli to zbuntowani żołnierze tatarscy, którym zaległy żołd wypłacono w postaci nadań ziemskich. W niektórych wsiach muzułmanie mieszkają do dziś m.in. w Bohonikach i Kruszynianach.

Na mocy przywileju królewskiego z 1698 r. w Sokółce zezwolono osiedlać się Żydom.

W połowie XIX wieku funkcjonowała w Sokółce szkoła leśna, której kierownikiem był chorąży Walery Wróblewski, absolwent Instytutu Leśnic- 
twa i Miernictwa w Petersburgu, Brał udział w wydawaniu odezw i ulotek skierowanych przeciw caratowi. Wysyłał do wsi agitatorów zwanych leśnikami, którzy nawoływali do powstania.

W 1921 r. została założona przez Sejmik Powiatowy Gazeta Sokólska. Celem czasopisma, wychodzącego co miesiąc było informowanie ludności o pracy i zamierzeniach samorządu. Czasopismo zawierało też dodatek poświęcony rolnictwu, hodowli i budownictwu cementowemu. Wskutek wad organizacyjnych Gazeta Sokólska przestała wychodzić od 1925 r. Sejmik zadbał też o kulturę czytelniczą mieszkańców sokólszczyzny poprzez założenie w 1933 r. centrali ruchomych bibliotek.

W 1939 r. mieszkało w Sokółce 7000 osób, w tym 3000 narodowości żydowskiej.

W okresie okupacji miasto poniosło ogromne straty materialne i moralne. Hitlerowcy wymordowali sokólskich Żydów, zginęło wielu Polaków zaangażowanych w ruch oporu.

24 lipca 1944 r. Sokólka została wyzwolona przez oddziały 49 Armii Frontu Białoruskiego. Miasto było zniszczone w 25\%.

Lata powojenne to okres odbudowy ze zniszczeń wojennych oraz czas rządów komunistycznych. Bardzo dynamiczny rozwój miasta nastapił w latach siedemdziesiątych.

\section{Szkolnictwo w przeszłości}

Stan nauczania szkolnego w regionie sokólskim był bardzo niski, a do tego istniejące szkółki były prowadzone pod kątem zaspokajania potrzeb religijnych. Administrator dóbr królewskich na tych terenach zobowiązał tutejszych proboszczów do utrzymywania bakałarza do uczenia dzieci.

Po powstaniu styczniowym zaborcy zamknęli szkoły parafialne, a następnie zaczęli zakładać szkoły gminne („wałostnyje ucziliszcza”) z językiem wykładowym rosyjskim, w których uczono nawet pacierza, katechizmu i historii świętej. Język polski ze szkół został wyrugowany.

Ludność chcąc zachować swój ojczysty język wśród dzieci, posługiwała się nauczaniem tajnym, domowym. Wieś zwykle wynajmowała niedoszłego seminarzystę, organistę lub oficjalistę, który pod nazwą „dyrektora”, za utrzymanie i niedużą opłatę, nauczał po domach.

Nieliczne przed I wojną światową szkolnictwo początkowe (przymusu nauczania nie było) podczas okupacji niemieckiej było zdezorganizowane, zarówno z powodu braku sił nauczycielskich i funduszów na ten cel. 
Z chwilą odzyskania niepodległości w 1919 r. sytuacja się poprawiła. Założono sieć szkół powszechnych, które nie były dostatecznie zasobne w pomoce naukowe. Region sokólski był pomijany przez Kuratorium Brzeskie, któremu podlegał, przy planowaniu budowy szkół i rozdziale funduszów na ten cel.

W roku 1933 została wybudowana przez społeczność sokólską i oddana do użytku 7-klasowa szkoła powszechna w Sokółce. Jest to gmach piętrowy, murowany i skanalizowany. W owym czasie region sokólski posiadał 7 szkółprywatnych: szkoła Salezjańska w Różanymstoku, 6 szkółżydowskich: w Dąbrowie Białostockiej, Suchowoli, Janowie, Kuźnicy i 2 w Sokółce; oraz 137 publicznych.

\section{Rozwój bibliotek w Sokólce i regionie}

Województwo białostockie w okresie międzywojennym cechował niedorozwój wszystkich dziedzin życia. Niepomyślnie też rozwijało się w tym czasie szkolnictwo i oświata. Jedną z przyczyn tego stanu rzeczy stanowił fakt braku samodzielnego kuratorium okręgu szkolnego. ${ }^{3}$ Brak opieki ze strony władz oświatowych sprawiał, że poziom oświaty był katastrofalny, gdyż $23 \%$ mieszkańców powyżej 10 lat nie umiało czytać i pisać. ${ }^{4}$

W latach 30-tych tak jak w całym kraju również w regionie sokólskim rozwijał się ruch kulturalno-oświatowy prowadzony przez różnorodne organizacje i stowarzyszenia, takie jak: Koła Związku Młodzieży Wiejskiej, Katolickiego Stowarzyszenia Młodzieży, Oddziału Związku Strzeleckiego, Straży Pożarnej, jedną z form tej działalności było tworzenie bibliotek, było ich na terenie powiatu około 60 . Posiadały przeciętnie po $200-300$ książek. Stan ich świadczył o potrzebie książki odczuwanej przez wieś. Młodzież wiejska nieraz sama zakładała biblioteczki tworzone przeważnie $\mathrm{z}$ darów, a więc z przygodnej zbieraniny książek i broszur, często o niskiej wartości kulturalnej.

W Sokółce największa biblioteka licząca ponad 5000 woluminów mieściła się przy Komendzie Policji Państwowej co nie stanowiło zachęty do korzystania z jej zbiorów. ${ }^{5}$

Do zasobniejszych bibliotek należała też biblioteka Związku Nauczycielstwa Polskiego. Miała ona jednak charakter zamknięty. Dlatego też najczęstszy kontakt z książką starszego społeczeństwa następował poprzez uczniów korzystających z bibliotek szkolnych. 
W 1833 roku, Sejmik Powiatowy w Sokółce założył centralę ruchomych bibliotek, tzw. „kompletów”, przeznaczonych dla zaspokojenia potrzeb czytelniczych w powiecie. Rozwój działalności na tym odcinku przedstawia następujące zestawienie.

Tabela $1^{6}$

\begin{tabular}{|c|c|c|c|c|}
\hline Lata & $1933 / 34$ & $1934 / 35$ & $1935 / 36$ & $1936 / 37$ \\
\hline Liczba kompletów ruchomych & 12 & 16 & 21 & 25 \\
\hline $\begin{array}{c}\text { Liczba kompletów ruchomych } \\
\text { depozytowych }\end{array}$ & - & - & - & 9 \\
\hline Liczba tomów depozytowych & - & - & - & 583 \\
\hline Liczba tomów własnych/centrli & 593 & 901 & 1854 & 1571 \\
\hline Liczba czytelników & 327 & 259 & 718 & 445 \\
\hline Liczba wypożyczeń & 1524 & 2304 & 3972 & 1867 \\
\hline
\end{tabular}

Pochodzenie funduszów na cele biblioteczne (zł):

Tabela $2^{7}$

\begin{tabular}{|c|c|c|c|c|}
\hline Lata & $\mathbf{1 9 3 3 / 3 4}$ & $\mathbf{1 9 3 4 / 3 5}$ & $\mathbf{1 9 3 5 / 3 6}$ & $\mathbf{1 9 3 6 / 3 7}$ \\
\hline Min. W.R. i O.P. & 1000 & - & - & - \\
\hline Wydział Powiatowy & 500 & 800 & 500 & 2060 \\
\hline Gminy & - & - & - & 1060 \\
\hline
\end{tabular}

Min.W.R.i O.P. w latach trzydziestych przeznaczyło na cele biblioteczne $w$ regionie sokolskim jednorazową kwotę $1000 \mathrm{zł}$. Jedynie Wydział Powiatowy przez cały czas trwania centrali ruchomych bibliotek (19331937), przeznaczał na ten cel określone kwoty pieniężne.

W 1937/38 r. oddano do użytku 6 bibliotek gminnych. Były one zaczątkiem central gminnych bibliotek ruchomych w gminach: Szudziałowo, Odelsk, Kuźnica, Dąbrowa, Suchowola, Nowy Dwór. Gminy te począwszy od 1937 roku miały świadczyć na cele biblioteczne rocznie kwoty w wysokości od 100 do $200 \mathrm{zt}^{8}{ }^{8}$ Pozostałe biblioteki miały powstać w 1939 r. ${ }^{9}$

Po wybuchu II wojny światowej Sokółka była okupowana przez trzy lata. Władze okupacyjne konsekwentnie realizowały zalecenie Hitlera z dnia 15 kwietnia 1940 r. pt. „Kilka uwag o traktowaniu obcoplemieńców na wschodzie" a dotyczące m.in. stanu oświaty dla tej ludności. ${ }^{10}$ Likwidacji uległy więc wszystkie szkoły i biblioteki. 
Książki w miejscowych bibliotekach zostały przewiezione na plac targowy w Sokółce, gdzie wypróbowanym już przedtem sposobem (praktykowanym w faszystowskich Niemczech) spłonęły na stosie. Część ich jednak została przez miejscową ludność uratowana i przechowana. Krążyły później przez lata okupacji z rąk do rąk tworząc swoisty system wypożyczeń międzysąsiedzkich. Stanowiły też pomoc w prowadzonym powszechnie w mieście i na wsi tajnym nauczaniu. Pierwsze lata po zakończeniu II wojny światowej to okres trudnych zmagań o odbudowanie zniszczeń wojennych, lecz młoda władza ludowa troskę o chleb łączyła z troską o powszechną oświatę i kulturę.

\section{a) Biblioteka Publiczna Miasta i Gminy w Sokólce - Powstanie i rozwój sieci bibliotecznych w powiecie sokólskim}

We wrześniu 1946 r. powstała Powiatowa Biblioteka Publiczna w Sokółce, stan jej księgozbioru na dzień 1 sierpnia 1947 r, przedstawiał się następująco:

Tabela $3^{11}$

\begin{tabular}{|l|r|}
\hline Liczba tomów ogółem & 1492 \\
\hline z tego zinwentaryzowanych & 1309 \\
\hline zabezpieczonych & 27 \\
\hline z liczby ogółem zakupionych & 87 \\
\hline otrzymano z przydziału władz państwowych & 950 \\
\hline ze zbiórki & 67 \\
\hline z darów & 190 \\
\hline z innych wpływów & 207 \\
\hline
\end{tabular}

W ogólnej liczbie książek w bibliotece powiatowej w drugiej połowie 1947 r. znaczny udział miały książki pochodzące z zakupu i przydziałów władz państwowych. Wiązało się to ze wzrostem produkcji wydawniczej w kraju.

W dalszym ciągu jeszcze $31 \%$ zbiorów biblioteki stanowiły dary społeczeństwa. Były wśród nich pozycje cenne i wartościowe. Większość jednak reprezentowała trzeciorzędną literaturę sensacyjną. Zdarzały się też książki zawierające treści wrogie Polsce Ludowej o wymowie antyradzieckiej i antysemickiej.

Na koniec 1948 r. stan zbiorów Powiatowej Biblioteki w Sokółce wyrażał șię liczbą 3.341 książek. Z biblioteki korzystało w tym czasie 291 czytelników. 
Zgodnie z Pismem Okólnym nr 54 w sprawie organizacji bibliotek gminnych ${ }^{12}$, PBP w Sokółce przystappiła we wrześniu 1948 r. do ich organizacji w powiecie. Biblioteki powstały w 9 gminach na 12 istniejacych. W pozostałych 3 gminach zorganizowano biblioteki w 1949 r. Jednocześnie obok istniejącej biblioteki powiatowej w Sokółce, działała biblioteka miejska dla bezpośredniej obsługi czytelników w mieście. Na mocy zarządzenia Ministra Kultury i Sztuki z 16 lipca 1954 roku nastąpiło połączenie bibliotek miejskich z powiatowymi w miastach będących siedzibą powiatu i powołanie na miejsce dotychczasowych gmin nowych jednostek administracyjnych - gromadzkich rad narodowych. ${ }^{13}$

Sieć bibliotek publicznych w powiecie sokólskim w końcu 1956 r. po przekazaniu byłych dwóch bibliotek gminnych i 39 punktów bibliotecznych nowo powstałemu powiatowi dąbrowskiemu oraz rozwiązaniu biblioteki gminnej w Sokółce przedstawiała się następująco: Powiatowa i Miejska Biblioteka Publiczna w Sokółce, 17 bibliotek gromadzkich i 140 punktów bibliotecznych. Z ogólnej liczby bibliotek 8 powstało w ciagu 1956 r. ${ }^{14}$ Były to biblioteki w: Białousach, Krasnem, Kamionce Starej, Rozedrance Starej, Nowowoli, Wierzchlesiu i Góranach. Liczba czytelników zarejestrowanych przez te biblioteki wynosiła przeciętnie 300 czytelników na jedną bibliotekę.

W latach 1955-1956 nastappił w powiecie żywiołowy rozwój punktów bibliotecznych. Masowa ich organizacja miała na celu możliwie szybkie dotarcie $z$ książką do czytelnika. Niesłuszne natomiast były tendencje do uzyskania efektów ilościowych. Część z wykazanych w statystykach punktów istniało tylko na papierze. Tak na przykład liczba punktów bibliotecznych w powiecie w 1958 r. zmniejszyła się do 96 ze 143 wykazanych w 1957 r. ${ }^{16}$ Koła Związku Młodzieży Wiejskiej typowały ze swego grona osoby, którym powierzano prowadzenie punktów bibliotecznych. ${ }^{17}$

W związku z utworzeniem w 1976 r. Urzędu Miasta i Gminy Sokółka, Miejska Biblioteka Publiczna została przemianowana na Bibliotekę Publiczną Miasta i Gminy Sokółka - pełniąc tym samym funkcję biblioteki rejonowej.

W rejonie Biblioteki Publicznej Miasta i Gminy Sokółka rozpoczęły swoją działalność w 1980 r. 4 większe biblioteki zakładowe: Czarna Białostocka Zakłady Przemysłu Drzewnego i Agrometu; Krynki - przy garbarni, Sokółka - Zakłady Stolarki Budowlanej.

Znaczącym osiągnięciem roku 1987 było otwarcie w czasie Dni Oświaty, Kultury, Książki i Prasy Filii Bibliotecznej nr 1 na Osiedlu Zielonym w Sokółce. 
Jak wyglądał stan sieci bibliotecznej w regionie sokólskim ilustruje poniższa tabela.

Rozwój sieci bibliotek i punktów bibliotecznych w powiecie sokólskim w latach 1956-1994

Tabela nr $4^{18}$

\begin{tabular}{|r|r|r|r|r|}
\hline Rok & $\begin{array}{c}\text { Liczba } \\
\text { bibliotek }\end{array}$ & $\begin{array}{c}\text { Liczba filii } \\
\text { bibliotecznych }\end{array}$ & $\begin{array}{c}\text { Liczba } \\
\text { czytelni }\end{array}$ & $\begin{array}{c}\text { Liczba punktów } \\
\text { bibliotecznych }\end{array}$ \\
\hline 1956 & 17 & - & - & 140 \\
\hline 1959 & 15 & 2 & - & 125 \\
\hline 1961 & 15 & 2 & 3 & 132 \\
\hline 1962 & 14 & 2 & 3 & 130 \\
\hline 1965 & 16 & 2 & 3 & 142 \\
\hline 1966 & 17 & 2 & 5 & 145 \\
\hline 1967 & 18 & 2 & 7 & 168 \\
\hline 1968 & 19 & 2 & 7 & 148 \\
\hline 1972 & 15 & 7 & 8 & 154 \\
\hline 1973 & 8 & 14 & 8 & 148 \\
\hline 1974 & 8 & 15 & 9 & 149 \\
\hline 1978 & 7 & 23 & 8 & 166 \\
\hline 1979 & 6 & 15 & 8 & 117 \\
\hline 1981 & 8 & 10 & 8 & 105 \\
\hline 1987 & 8 & 6 & 7 & 30 \\
\hline 1990 & 5 & 16 & 6 & 23 \\
\hline 1991 & 5 & 16 & 6 & 20 \\
\hline 1994 & 4 & 10 & 6 & 18 \\
\hline
\end{tabular}

Do roku 1978 zmniejszono liczbę bibliotek gromadzkich, a zwiększono liczbę filii bibliotecznych. Na skutek kryzysu gospodarczo-politycznego kraju nastąpił spadek liczby bibliotek, filii bibliotecznych i ich punktów. Ilustruje to tabela nr 4.

\section{Dobór i struktura zbiorów}

W latach 1948-1949 Naczelna Dyrekcja Bibliotek przydzielała poszczególnym bibliotekom gminnym komplety książek w ilości 500 woluminów, z których 218 stanowiły książki dla dorosłych, 128 książek dla dzieci i 154 popularno-naukowych. ${ }^{19}$ 
W ten sposób ukształtowała się struktura zbiorów bibliotek gminnych zawierająca około 50\% literatury pięknej, $25 \%$ literatury dziecięcej i około $30 \%$ literatury popularnonaukowej.

Komplety książek przeznaczonych dla bibliotek powiatowych zawierały więcej książek prezentujących zagadnienia marksizmu i leninizmu.

Oprócz przydziałów powiatowa biblioteka publiczna w Sokółce zakupiła też książki ze środków samorządowych, w 1946 r. 87 woluminów, a w 1948 r. 112 woluminów. ${ }^{20}$

Centralny zakup nie uwzględniał zróżnicowania regionalnego kraju i nie był w stanie uwzględnić potrzeb czytelniczych poszczególnych środowisk. W efekcie powiatowa biblioteka w Sokółce otrzymała po kilkanaście egzemplarzy takich książek jak: Aleksandr Frołow Szybkość wytopu stali, Tadeusz Laskowski Potokowa produkcja maszyn, Jerzy Zieliński Jak wykonalem 721\% normy, Jan Dzierżyński Rola odpadków użytkowych, Życie $i$ walka Józefa Stalina i wiele podobnych. ${ }^{21}$

W 1956 r. nastapiła całkowita decentralizacja zakupu książek, który stanowił jedną z najbardziej odpowiedzialnych i niełatwych czynności bibliotekarza. W związku z czym polecono PiMBP w Sokółce powołanie komisji doboru książek, w skład której miały wejść osoby reprezentujące różnego rodzaju dziedziny wiedzy. Komisja ta ze względu na swój społeczny charakter nie dała spodziewanych efektów.

$\mathrm{Na}$ profil uzupełnienia zbiorów w latach 1952-1956 miała wpływ sytuacja społeczno-polityczna, która zaciążyła nad koncepcją kompletowania zbiorów. Do walki o fałszywie pojętą kolektywizację wsi wciagnięte zostały także biblioteki, do których zaczęło trafiać więcej literatury propagującej kolektywizację.

W praktyce planowane akcje nie były realizowane, a przesyłane książki pełniły funkcję jednostek statystycznych.

W 1957 r. przeprowadzono pierwszą selekcję w bibliotekach powiatu sokólskiego, w wyniku której wycofano z księgozbiorów 7472 woluminów, w tym w bibliotekach gromadzkich 6526 woluminów i w PiMBP 846 woluminów. ${ }^{22}$ Kolejne selekcje przeprowadzone w następnych latach (ogółem do 1994 roku wycofano około 50000 książek) spowodowały zmianę struktury zbiorów bibliotecznych na korzyść literatury pięknej. Selekcje bowiem dotyczyły przede wszystkim literatury popularnonaukowej i społeczno - politycznej. Na przykład w PiMBP stanowiła ona 92\% wszystkich książek. ${ }^{23}$

W początku lat osiemdziesiątych struktura zbiorów w gminie była poprawna i zbliżona do zalecanego w kraju wzorca. W 1988 r. zanotowano 
najniższy od wielu lat wskaźnik zakupu nowości - 14 woluminów na 100 mieszkańców. ${ }^{24} \mathrm{Z}$ powodu braku pieniędzy drastycznie ograniczono ilość prenumerowanej prasy w filiach bibliotecznych, które otrzymywały tylko po 3 tytuły, a od lipca 1990 r. zaprzestano prenumeraty. 25

Wśród wycofanej literatury na podstawie wykazu nr 14 Ministerstwa Kultury i Sztuki z 1990 r. znalazło się m.in. ponad 700 woluminów literatury marksistowsko-leninowskiej.26

Najcięższym rokiem dla biblioteki powiatu sokólskiego był rok 1991 . Czytelnikowi trudniej było wypożyczyć coś z nowości. Do końca 1990 r. biblioteki finansowane były z Funduszu Rozwoju Kultury, a od 1991 r. wszystkie koszty utrzymania spadły na budżet gmin. Konsekwencją dla biblioteki powiatu sokolskiego były znaczne ograniczenia finansowe na zakup książek, prenumeratę czasopism oraz utrzymanie punktów bibliotecznych w powiecie.

\section{Rozwój czytelnictwa}

Początki były trudne, brak książek lokali bibliotecznych, słaba kadra (bez odpowiednie go wykształcenia), brak nawyków czytelniczych sprawiły, że w pierwszych latach po wojnie rozwój czytelnictwa postępował bardzo powoli. W 1947 r. zanotowano w powiecie 425 czytelników z tego 327 stanowili czytelnicy na wsi. ${ }^{27}$

W miarę podnoszenia się stanu powszechnej oświaty oraz powiększania się księgozbiorów bibliotek publicznych nastąpił wzrost liczby czytelników i wypożyczonych książek. Wzrost ten ilustruje tabela nr $5 .^{28}$

Rozwój czytelnictwa w powiecic sokólskim i mieście Sokólce w latach 1957-1974

Tabela nr 5

\begin{tabular}{|r|r|r|r|}
\hline Rok & Czytelnicy ogołem & w mieście & na wsi \\
\hline 1957 & 7488 & 833 & 6565 \\
\hline 1958 & 7555 & 817 & 6738 \\
\hline 1959 & 9739 & 935 & 8804 \\
\hline 1960 & 10888 & 1167 & 9721 \\
\hline 1961 & 11103 & 1206 & 9897 \\
\hline 1962 & 11103 & 1206 & 9897 \\
\hline 1963. & 11179 & 1395 & 9784 \\
\hline
\end{tabular}




\begin{tabular}{|l|r|r|r|}
\hline Rok & Czytelnicy ogólem & w mieście & na wsi \\
\hline 1964 & 11872 & 1564 & 10208 \\
\hline 1965 & 12614 & 1650 & 10964 \\
\hline 1966 & 13178 & 1788 & 11390 \\
\hline 1967 & 13414 & 1975 & 11439 \\
\hline 1968 & 14018 & 2106 & 11912 \\
\hline 1969 & 14563 & 2317 & 12246 \\
\hline 1970 & 14877 & 2284 & 12593 \\
\hline 1971 & 15128 & 2457 & 12671 \\
\hline 1972 & 15128 & 2457 & 12671 \\
\hline 1973 & 14758 & 2413 & 12545 \\
\hline 1974 & 15242 & 2673 & 15269 \\
\hline
\end{tabular}

Istotną rolę na rozwój czytelnictwa w powiecie sokólskim odgrywała kadra pracująca w bibliotekach. W pierwszych latach władzy ludowej sieć biblioteczną organizowali nauczyciele. ${ }^{29}$

Sytuacja ulegała pogorszeniu z chwila utworzenia przy radach gromadzkich bibliotek, do których kierowano często ludzi nie przygotowanych, nie umiejących sprostać kulturalno-oświatowym funkcjom bibliotek. W 1957 r. z ogólnej liczby pracujących bibliotekarzy wykształcenie średnie posiadało jedynie $12 \%$ zatrudnionych. ${ }^{30} \mathrm{~W}$ latach dziewięćdziesiątych zaś stan wykształcenia pracowników bibliotek zatrudnianych na stanowiskach bibliotekarzy przedstawia się następująco: 14 osób posiada ukończone studia pomaturalne z zakresu bibliotekarstwa, a 3 osoby ukończyły uniwersyteckie studia bibliotekoznawcze.

Dla rozwoju czytelnictwa nie bez znaczenia są także warunki w jakich odbywa się proces upowszechniania książki. Nie zawsze władze terenowe przejawiały dostateczną troskę o zapewnienie bibliotekarzom lokali odpowiednich do rangi pełnionych przez nie społecznych funkcji. Jaskrawym przykładem był lokal BPMiG w Sokółce, która zmieniała go dziewięcio-krotnie, przy czym decyzje administracyjne dotyczące zmiany nie wynikały $\mathrm{z}$ chęci poprawienia warunków pracy biblioteki, lecz były one determinowane potrzebami innych instytucji. Sytuacja lokalowa biblioteki uległa poprawie z chwilą utworzenia gmin.

Do rozwoju czytelnictwa na wsi przyczyniły się punkty biblioteczne. Zorganizowano je we wsiach, których liczba mieszkańców osiągała 1000 i więcej. W powiecie sokólskim w 1974 r. z ogólnej liczby 175 takich wsi, punkty istniały w $152 .{ }^{31} \mathrm{Z}$ biegiem lat liczba punktów zmniejszała się stopniowo i tak w roku 1994 punktów bibliotecznych w powiecie sokól- 
skim istnieje $16{ }^{32}$ Stało się to za przyczyną zmian administracyjnych. Zlikwidowano etaty w bibliotekach w terenie. Powstały nowe gminy, których samorządy przejęły filie biblioteczne znajdujące się na ich terenie. ${ }^{33}$

Według ostatnich danych za rok 1994 struktura czytelników przedstawia się następująco: osoby pracujące - 592, emeryci i renciści - 205, niezatrudnieni - 249, młodzież - 781. ${ }^{34}$ Do 1993 r. wyszczególniono jeszcze grupę rolników, których zarejestrowanych było 28 oraz osób fizycznych - 150.35

Tabele 6 i 7 przedstawiają czytelnictwo w mieście i na wsi w ciągu ostatnich dziesięciu lat. Liczba czytelników w mieście utrzymuje się stale prawie w jednakowym wskaźniku w każdym roku, wzrasta natomiast liczba wypożyczeń, która podyktowana jest wzrostem bezrobocia w regionie sokólskim oraz cenami książek w punktach księgarskich. Stan księgozbioru zaś ciągle pozostawia sporo do życzenia.

Liczba wypożyczeń na wsi wykazuje tendencje zwyżkowe, ale ze zmniejszeniem się liczby czytelników. Księgozbiór w punktach bibliotecznych w ciagu ostatnich lat ulega zmniejszeniu z powodu selekcji zbiorów. Brak funduszów uniemożliwia dokonanie większych zakupów, które uatrakcyjniałyby ofertę bibliotek i przyciągnęły nowych czytelników.

\section{Czytelnictwo w mieście w latach 1985-1994}

Tabela nr 6

\begin{tabular}{|c|r|r|r|}
\hline Rok & $\begin{array}{c}\text { Stan księgozbioru } \\
\text { w mieście }\end{array}$ & $\begin{array}{c}\text { Licba czytelników } \\
\text { w mieście }\end{array}$ & $\begin{array}{c}\text { Liczba } \\
\text { wypożyczeń }\end{array}$ \\
\hline 1985 & 73104 & 4572 & 110984 \\
\hline 1986 & 75916 & 4584 & 113448 \\
\hline 1987 & 79247 & 4070 & 123304 \\
\hline 1988 & 83285 & 5082 & 127676 \\
\hline 1989 & 85452 & 5084 & 127033 \\
\hline 1990 & 57743 & 3396 & 89015 \\
\hline 1991 & 57328 & 3337 & 88416 \\
\hline 1992 & 57736 & 3443 & 98538 \\
\hline 1993 & 57962 & 3419 & 102707 \\
\hline 1994 & 58419 & 3521 & 108259 \\
\hline
\end{tabular}




\section{Czytelnictwo na wsi w latach 1985-1994}

Tabela nr 7

\begin{tabular}{|l|r|r|r|}
\hline Rok & $\begin{array}{c}\text { Stan księgozbioru } \\
\text { na wsi }\end{array}$ & $\begin{array}{c}\text { Licba czytelników } \\
\text { na wsi }\end{array}$ & Liczba wypożyczeń \\
\hline 1985 & 122233 & 7605 & $\mathbf{1 4 5 2 9 1}$ \\
\hline 1986 & 125286 & 7736 & $\mathbf{1 4 3 8 7 1}$ \\
\hline 1987 & 127426 & 7751 & 145721 \\
\hline 1988 & 132 & 7704 & 143539 \\
\hline 1989 & & - & - \\
\hline 1990 & 34696 & 1821 & 32789 \\
\hline 1991 & 35158 & 1696 & 31493 \\
\hline 1992 & 34400 & 1690 & 33092 \\
\hline 1993 & 34381 & $\mathbf{1} 641$ & 34972 \\
\hline 1994 & 33859 & 1618 & 35657 \\
\hline
\end{tabular}

\section{Działalność oświatowa biblioteki}

W latach pięćdziesiątych postawiono przed bibliotekarzami konkretne, choć niełatwe zadanie, aktywnego działania poprzez książkę. Zwrócono większą uwagę na czytelników. Pojawiły się w bibliotece hasła o książce, cytaty, gazetki ścienne, plakaty informacyjne, plansze czytelnicze, wystawy książek. Rozpoczęto też masową pracę z czytelnikami poprzez organizowanie wieczorów literackich, pogadanek, odczytów. Te formy pracy $\mathrm{z}$ czytelnikiem miały na celu zwrócenie uwagi na ważne momenty w życiu państwa polskiego.

Starano się również rozpowszechnić czytelnictwo książek fachowych na wsi, głównie literatury rolniczej. W latach 1967-1969 przeprowadzony był konkurs dla kobiet wiejskich pod hasłem: „Zdrowie i kulura podstawą współczesnej rodziny". Konkurs cieszył się w powiecie dużą popularnością, wzięło w nim udział prawie 15000 kobiet. $^{36}$

Miał on na celu popularyzowanie czytelnictwa książek z zakresu oświaty sanitarnej, gospodarstwa domowego i wychowania dzieci.

Następny konkurs pod nazwą „Książka rolnicza najlepszym doradcą w gospodarstwie" odbył się w Sokółce w 1970 r., do którego w powiecie zgłosiło się 1800 rolników, a do eliminacji przystąpiło 1300 osób. W ramach konkursu wypożyczono 3828 książek rolniczych. Wzrosła również prenumerata czasopism rolniczych na wsi o 670 egzemplarzy. ${ }^{37}$ 
Biblioteki przeprowadziły też w latach 1970-1975 szereg konkursów o zabarwieniu politycznym, były to turnieje pod hasłem: „Włodzimierz Lenin”, „Komuniści Białostocczyzny”, „Ruch robotniczy w walce o nowe jutro”, „Idee PPR wiecznie żywe”, „Wiem wszystko o Kraju Rad”. ${ }^{3 R}$

Biblioteki w powiecie sokólskim uczestniczyły też w konkursie „Złoty Kłos” organizowanym przez „Dziennik Ludowy” od 1964 r. Jego celem była popularyzacja wartościowej literatury współczesnej. W konkursie mógł wziąć udział każdy indywidualny czytelnik, koła przyjaciół książki, biblioteki, księgamie, kluby kultury i koła gospodyń wiejskich.

W „Dzienniku Ludowym” ukazywały się różnorodne materiały o książkach i ich autorach. Co roku typowano 10 książek. Redakcja zbierała opinie czytelników, a najciekawsze listy były drukowane i nagradzane. ${ }^{39} \mathrm{~W}$ styczniu 1980 r. dokonano w Warszawie podsumowania konkursu „Złoty Kłos” prowadzonego przez biblioteki w 1979 r. W finałowej imprezie uczestniczył dyrektor Biblioteki Publicznej Miasta i Gminy w Sokółce mgr Leonard Daszuta, który otrzymał pisemne zawiadomienie o przyznaniu nagrody za upowszechnianie czytelnictwa i za popularyzację książek zgłoszonych do plebiscytu „Złoty Kłos 1979”.

Do najbardziej popularnych i atrakcyjnych imprez czytelniczych organizowanych przez biblioteki należą spotkania z pisarzami. Odznaczają się one dużymi wartościami oświatowymi i wychowawczymi, rozbudzają bowiem zainteresowania czytelnicze.

Od 1995 r. Stowarzyszenie Civitas Christiana, Towarzystwo „Ziemia Sokólska" oraz Biblioteka Publiczna w Sokółce zaczęły organizować spotkania z poezją.

\section{b) Oddzial dla Dzieci w Bibliotece Publicznej Miasta i Gminy w Sokólce}

Oddział dla Dzieci w Bibliotece Publicznej w Sokółce utworzono w dniu 1 września 1966 r. Mieścił się on w jednym z pomieszczeń i nie posiadał czytelni, a jedynie wypożyczalnię o powierzchni $13 \mathrm{~m}^{2}$. Praca indywidualna z czytelnikiem była znikoma. Księgozbiór oddziału wynosił 1444 woluminów, a czytelników zarejestrowano 7111.

W wyniku starań w grudniu 1971 r. uzyskano nowy lokal w sąsiadującym z biblioteką publiczną budynku składającym się z trzech pomieszczeń: wypożyczalni i zaplecza (magazynu) co łącznie dawało $64 \mathrm{~m}^{2}$. Księgozbiór zawierał 5623 woluminów, a czytelników zarejestrowano $1020{ }^{40}$ 
W 1974 r. ogłoszono konkurs „Czytelnik przyprowadza nowego czytelnika”, kórego zasadniczym celem było zwiększenie zainteresowania książką i czasopismem jako narzędziem szeroko pojętego kształcenia i zaspokojenia potrzeb kulturalnych. W konkursie uczestniczyło 19 osób, dzięki którym uzyskano 41 nowych czytelników. ${ }^{41}$

Szczególnie szczęśliwym wydarzeniem dla Oddziału Dziecięcego było przekazanie 30 listopada $1985 \mathrm{r}$. nowego lokalu o powierzchni $134 \mathrm{~m}^{2}$. Wraz z otwarciem nowego lokalu zostały stworzone lepsze warunki do prowadzenia prac oświatowych. W wypożyczalni wywieszono piękno hasło: „Książka to najlepsza pomoc w nauce i niezawodny przyjaciel w życiu".

Biblioteka została urządzona estetycznie. Wolny dostęp do półek i możność przeglądania książek uczy samodzielności decyzji, a zarazem stwarza sytuację umożliwiającą pobudzenie nowych zainteresowań czytelniczych.

Wizualna propaganda biblioteczna, ma za zadanie nie tylko służyć informacją o zasobach, ale pobudzić ciekawość. Zaciekawieniu i zainteresowaniu książką służą głośne czytania fragmentów książek, opowiadania bajek, konkursy rysunkowe, wyświetlanie przé́roczy. W celu budzenia zainteresowań różnymi rodzajami literatury i różnymi dziedzinami wiedzy organizowane są wystawy tematyczne, katalożki zagadnieniowe, pogadanki, konkursy, spotkania autorskie i różnego typu zajęcia zespołowe z czytelnikami: gry literackie, quizy i zgadıj-zgadule.

Organizując konkurs pod hasłem „Nastolatki nie lubią wierszy?” zachęcono czytelników do zapoznania się z poezją wybitnych poetów i podjęcia próby tworzenia własnych wierszy. W 1992 r. ogłoszony został przez Wojewódzką Bibliotekę Publiczną w Białymstoku konkurs „Literackie spotkania młodych". Udział wzięło 6 osób, spośród których wybrano jednego uczestnika na eliminacje wojewódzkie. Zadaniem było przedstawienie własnej twórczości w formie książkowej z uwzględnieniem szaty graficznej książki. Uczestnicy byli podzieleni na dwie kategorie:

a) wedhug wieku;

b) wedhug form pracy.

Częste odwiedzanie przez czytelników biblioteki rodzi więzi emocjonalne i formuje grupki stałych bywalców: Koło Przyjaciół Biblioteki posiadające trzy zespoły - zespół kukiełkarski, recytatorsko-imprezowy i redagujący gazetki ścienne.

Oddział dla Dzieci realizuje również lekcje biblioteczne dla dzieci i młodzieży, a od 1988 r. tradycją się stały majowe wycieczki do biblioteki przedszkolaków sokólskich. ${ }^{42}$ Celem ich jest wskazanie drogi do bi- 
blioteki tym dzieciom, które nie miały okazji z nią się zetknąć, zapoznanie ze zwyczajami panującymi, w tej placówce, z księgozbiorem i techniką samodzielnego wybierania książek.

Podstawą dobrej pracy biblioteki dziecięcej jest odpowiednio dobrany księgozbiór. Niestety na skutek trudności finansowych od 1991 r. zakupuje się coraz mniej książek niż w minionych latach, w wyniku czego zanotowano spadek liczby wypożyczeń o 1846 książek i czytelników o $89 .{ }^{43}$

Czytelnictwo dzieci i młodzicży w latach 1983-1994

Tabela $8^{44}$

\begin{tabular}{|c|r|r|r|}
\hline Rok & Stan księgozbioru & Liczba czytelników & Liczba wypoyczeń \\
\hline 1983 & 12985 & 1050 & 24519 \\
\hline 1984 & 13048 & 1161 & 25973 \\
\hline 1985 & 13185 & 1209 & 26102 \\
\hline 1986 & 13279 & 1215 & 27497 \\
\hline 1987 & 13690 & 1359 & 30672 \\
\hline 1988 & 14308 & 1362 & 30053 \\
\hline 1989 & 14603 & 1363 & 22117 \\
\hline 1990 & 14466 & 1290 & 24767 \\
\hline 1991 & 13842 & 1201 & 22921 \\
\hline 1992 & 13823 & 1230 & 25390 \\
\hline 1993 & 13711 & 1250 & 27329 \\
\hline 1994 & 13981 & 1267 & 28612 \\
\hline
\end{tabular}

\section{c) Pedagogiczna Biblioteka Wojewódzka im. Wl. Spasowskiego} w Białymstoku - Filia w Sokółce

\section{Powstanie i działalność biblioteki}

Biblioteka Pedagogiczna w Sokółce rozpoczęła swą działalność w 1948 r. Początkowo istniała ona przy Inspektoracie Oświaty i Wychowania, zaś książki przekazane były przez szkoły i prywatnych właścicieli, które przetrwały lata wojny i okupacji. Księgozbiór początkowo był nieliczny, brakowało literatury metodycznej do poszczególnych przedmiotów nauczania. W następnych latach księgozbiór biblioteki zaczął wzrastać. Wypożyczano całe komplety książek nauczycielom, którzy pracowali w szkołach położonych poza Sokółką. 
Pracownicy biblioteki prowadzą szeroką działalność propagującą czytelnictwo książek wśród nauczycieli poprzez indywidualne doradztwo, udział w konferencjach pedagogicznych. W działalności biblioteki naczelną dewizą jest postęp pedagogiczny. W związku z tym została szeroko rozbudowana kartoteka zagadnieniowa, która ułatwia nauczycielom wyszukiwanie różnych materiałów na dany temat. I tak w latach osiemdziesiątych założony został kartkowy katalog nowości, katalog podręczników szkolnych i lektur szkolnych, a także katalog recenzji i biografii zalącznikowej.

Dużą rolę w postępie pedagogicznym odgrywają też czasopisma pedagogiczne. 14 maja 1981 r. została zorganizowana sesja popularnonaukowa oraz wystawa czasopiśmiennictwa pedagogicznego na temat: „Społeczne funkcje czasopism pedagogicznych". ${ }^{45}$

Filia Pedagogicznej Biblioteki Wojewódzkiej w Sokółce obsługuje nauczycieli z następujących gmin: Sokółka, Kuźnica Białostocka, Szudziałowo, Krynki, Korycin, Janów, Czarna Białostocka. Z czytelni biblioteki korzystają studenci uczelni białostockich, którzy są mieszkańcami regionu sokólskiego.

W latach osiemdziesiątych największym problemem działalności biblioteki był brak funduszy na zakup nowości pedagogicznych, metodycznych i naukowych. Od 1992 roku bibliotekarze prowadzą działalność marketingową w celu pozyskania środków na zakup książek do biblioteki.

Biblioteka Pedagogiczna w Sokółce stwarza możliwości wypożyczeń literatury fachowej dla rodziców, którzy mają trudności wychowawcze ze swymi dziećmi. ${ }^{46} \mathrm{~W}$ zbiorach znajdują się ponadto programy wspierające pracę nauczyciela nowatora, pracę z uczniem zdolnym, słabym i niedostosowanym społecznie.

Bibliotekarze udzielają wszechstronnej pomocy nauczycielom początkującym, studiującym, doskonalącym i specjalizującym się zawodowo.

Organizowane są również spotkania z pisarzami, redaktorami i ludźmi ze sceny politycznej. Optymalne wykorzystanie księgozbioru bibliotecznego uzyskuje się poprzez:

- informowanie nauczycieli o wartościowych pozycjach i nowościach pedagogicznych;

- sporządzanie wykazu literatury dla dyrektorów szkół z zakresu organizacji i zarządzania oświatą oraz hospitacji. ${ }^{47}$ 


\section{Czytelnictwo nauczycieli}

Według najnowszych danych z $1994 \mathrm{r}^{48}$ dotyczących czytelnictwa czasopism i książek przez nauczycieli z regionu sokolskiego okazało się, że:

a) najpoczytniejszymi czasopismami są:

- „Kwartalnik pedagogiczny";

- "Nowa Szkoła”;

- "Ruch Pedagogiczny";

- „Życie Szkoły”;

- „Problemy Opiekuńczo-Wychowawcze”;

- „Biuletyny Kieleckie”. ${ }^{49}$

b) najpoczytniejszymi książkami są:

- Wincenty Okoń - „Wprowadzenie do dydaktyki”;

- Krzysztof Kruszewski - „Sztuka Nauczania”;

- Stanisław Kott - „Historia wychowania”so

- Łukasz Kurdybacha - „Historia wychowania”;

- Tadeusz Tomaszewski - „Psychologia”;

- Stefan Wołoszyn - „Dzieje wychowania i myśli pedagogicznej w zarysie".

Liczba czytelników - nauczycieli warunkowana jest m.in. ilością osób studiujących lub doskonalących się zawodowo. Od 1993 r. zauważa się gwałtowny wzrost liczby nauczycieli korzystających z Biblioteki Pedagogicznej. Między 1992 r. a 1995 r. do biblioteki zapisało się 127 osób, w tym 56 nauczycieli i 71 czytelników nie związanych z tym zawodem. Wzrost czytelnictwa uwarunkowany jest zarówno zwiększoną liczbą studentów na uczelniach, jak i terminem do 2000 roku danym dla nauczycieli nie mających wyższego wykształcenia na zdobycie odpowiednich kwalifikacji do wykonywania zawodu nauczycielskiego - co ilustrują poniższe dane statystyczne. 


\section{Czytelnictwo nauczycieli regionu sokólskiego w latach 1985-1994}

Tabela nr $9^{51}$

\begin{tabular}{|c|c|c|c|c|c|c|c|c|}
\hline \multirow[b]{2}{*}{ Rok } & \multirow{2}{*}{$\begin{array}{l}\text { Liczba } \\
\text { czytel- } \\
\text { ników }\end{array}$} & \multicolumn{3}{|c|}{ wtym } & \multirow{2}{*}{$\begin{array}{c}\text { Liczba } \\
\text { wypożyczeń } \\
\text { ogólem }\end{array}$} & \multicolumn{3}{|c|}{ w tym } \\
\hline & & nauczyciele & $\begin{array}{l}\text { nauczyciele } \\
\text { studiujący }\end{array}$ & $\begin{array}{l}\text { inni } \\
\text { czytelnicy }\end{array}$ & & nauczyciele & $\begin{array}{l}\text { nauczyciele } \\
\text { studiujazcy }\end{array}$ & $\begin{array}{l}\text { inni } \\
\text { cyytelnicy }\end{array}$ \\
\hline 1985 & 399 & 316 & 212 & 83 & 5326 & 4586 & 3803 & 740 \\
\hline 1986 & 516 & 478 & 213 & 38 & 6681 & 6296 & 3874 & 385 \\
\hline 1987 & 601 & 566 & 308 & 35 & 10426 & 10079 & 6134 & 347 \\
\hline 1988 & 622 & 580 & 289 & 42 & 9853 & 9435 & 5982 & 418 \\
\hline 1989 & 640 & 592 & 315 & 48 & 11878 & 11183 & 6135 & 695 \\
\hline 1990 & 560 & 536 & 336 & 24 & 9281 & 9113 & 5443 & 168 \\
\hline 1991 & 528 & 492 & 346 & 36 & 6907 & 6763 & 4872 & 144 \\
\hline 1992 & 512 & 468 & 312 & 44 & 6573 & 6355 & 6137 & 218 \\
\hline 1993 & 559 & 491 & 324 & 68 & 6855 & 6430 & 5125 & 425 \\
\hline 1994 & 639 & 524 & 362 & 115 & 8907 & 6951 & 4368 & 1956 \\
\hline
\end{tabular}

Zbiory Biblioteki Pedagogicznej w Sokółce od 1993 r. zaczęły stopniowo wzrastać. Poza tym ma bogaty księgozbiór informacyjno-bibliograflczny. Wzrasta też liczba zbiorów audiowizualnych. Zestawienie liczbowe zbiorów przedstawia tabela 10 .

\section{Zbiory Biblioteki Pedagogicznej w Sokólce w latach 1985-1994}

Tabela nr $10^{52}$

\begin{tabular}{|c|c|c|c|c|c|c|c|c|c|c|}
\hline & \multicolumn{10}{|c|}{ Rok } \\
\hline & 1985 & 1986 & 1987 & 1988 & 1989 & 1990 & 1991 & 1992 & 1993 & 1994 \\
\hline Wydawnictwa zwarlc & 13416 & 14381 & 15039 & 16279 & 16984 & 17256 & 17558 & 17974 & 18265 & 18806 \\
\hline $\begin{array}{l}\text { Wydawnictiva peri- } \\
\text { odyczne }\end{array}$ & 550 & 598 & 640 & 696 & 753 & 813 & 813 & 813 & 813 & 813 \\
\hline $\begin{array}{l}\text { Zbiory } \\
\text { audiowizualnc }\end{array}$ & 227 & 252 & 302 & 323 & 356 & 379 & 381 & 387 & 393 & 397 \\
\hline $\begin{array}{l}\text { Wyd. zwarle w jęz. } \\
\text { obcych }\end{array}$ & 38 & 49 & 58 & 64 & 69 & 72 & 72 & 74 & 74 & 78 \\
\hline Częstotliwosć zakupu & 3 & 8 & 7 & 8 & 8 & 7 & 4 & 8 & 13 & 33 \\
\hline $\begin{array}{l}\text { Wielkość zbiorów zgro- } \\
\text { madzonych w ciagu roku: }\end{array}$ & & & & & & & & & & \\
\hline $\begin{array}{l}\text { - liczba tytuib́w } \\
\text { - liczba cgzcmplarzy }\end{array}$ & $\begin{array}{l}510 \\
597\end{array}$ & $\begin{array}{l}724 \\
935\end{array}$ & $\begin{array}{l}870 \\
978\end{array}$ & $\begin{array}{l}832 \\
940\end{array}$ & $\begin{array}{l}796 \\
834\end{array}$ & $\begin{array}{l}440 \\
516\end{array}$ & $\begin{array}{l}268 \\
304\end{array}$ & $\begin{array}{l}230 \\
279\end{array}$ & 208 & $\begin{array}{l}420 \\
545\end{array}$ \\
\hline Księgozbiór podręczny & 776 & 795 & 810 & 828 & 840 & 850 & 853 & 861 & 873 & 883 \\
\hline $\begin{array}{l}\text { Księgozbior informa- } \\
\text { cyjno-bibliograficzny }\end{array}$ & 70 & 79 & 90 & 96 & 100 & 103 & 105 & 106 & 108 & 110 \\
\hline $\begin{array}{l}\text { Ksieggozbiór biblioteczany } \\
\text { (z nauki o ksiażce) }\end{array}$ & 143 & 148 & 154 & 159 & 165 & 167 & 173 & 174 & 175 & 177 \\
\hline
\end{tabular}


Dzięki wzbogacaniu się księgozbioru Biblioteki Pedagogicznej w Sokółce, nauczyciele z regonu sokólskiego mają szansę na dokształcanie się i doskonalenie swojego warsztatu zawodowego.

\section{Przekształcenie Filii PBW w Sokólce w Rejonowy Zespół Doskonale- nia Nauczycieli}

1 stycznia 1993 r. Kurator Oświaty w Białymstoku powołał Zespół Placówek Doskonalenia Nauczycieli ${ }^{53}$, w skład którego weszły Pedagogiczna Biblioteka Wojewódzka im. Wł. Spasowskiego i Wojewódzki Ośrodek Metodyczny. Na bazie byłych filii Biblioteki Pedagogicznej w Białymstoku powołane zostały Rejonowe Zespoły Doskonalenia Nauczycieli. Pozwala to na lepsze wykorzystanie bazy lokalowej, wzbogacenie informacji z zakresu pedagogiki i psychologii. Umożliwia wymianę doświadczeń w pracy doradców metodycznych i nauczycieli bibliotekarzy oraz przybliża różne formy działalności pedagogicznej w szkołach na terenie województwa.

Rejonowy Zespół Doskonalenia Nauczycieli w Sokółce jest miejscem, gdzie stworzona została baza umożliwiająca nauczycielom regionu sokolskiego korzystanie z kompleksowej pomocy doradczo-instruktażowej w postaci doradztwa metodycznego, nowoczesnych środków dydaktycznych i zbiorów audiowizualnych oraz fachowego księgozbioru. Dzięki temu nauczyciele twórczy rozwiną i upowszechnią działalność innowacyjną i przeprowadzone eksperymenty.

Pracownicy Biblioteki Pedagogicznej w Sokółce wykonują na bieżąco zestawienia bibliograficzne związane z tematami konferencji metodycznych czy konsultacji zbiorowych nauczycieli.

\section{d) Biblioteki szkolne}

\section{Najstarsza biblioteka szkolna przy Szkole Podstawowej nr 1 w Sokól- ce}

W okresie okupacji hitlerowskiej działalność szkół została zawieszona. Po opuszczeniu miasta przez wojska niemieckie w lipcu 1944 r. budynki szkolne zostały zajęte przez rannych i chorych. Budynki Szkoły Podstawowej nr 1 i 2 były poważnie uszkodzone. Inwentarze szkolne nie istniały. Zapał nauczycieli, rodziców i uczniów zdołał jednak zaradzić wszystkiemu. Od rạzu też zabrano się do porządkowania ocalałych resztek biblioteki szkol- 
nej. Ściągano książki oddane w czasie wojny na przechowanie osobom prywatnym, przeprowadzono zbiórkę wśród miejscowego społeczeństwa. W 1946 r. do biblioteki dotarły pierwsze przydziały od centralnych władz oświatowych. W ten sposób księgozbiory były zasilane aż do 1961 r. co pozwoliło racjonalnie wyposażyć szkoły w najpotrzebniejsze książki. Centralny zakup objął podstawowe poradniki metodyczne oraz inne książki pomocnicze dla nauczycieli. Biblioteka zasilana była również publikacjami o tematyce gospodarczej i społecznej. W rezultacie brakowało atrakcyjniejszej literatury dla uczniów.

Centralny zakup pomógł w uzupełnieniu zbiorów w dzieła ogólnoinform acyjne: encyklopedie oraz słowniki językowe i rzeczowe. Dzięki temu kącik czytelniany mógł rozwinąć swą pracę pedagogiczną.

W roku szkolnym 1963/64 zapoczątkowało swoją działalność uczniowskie „Koło Przyjaciół Książki”. Istniały dwie sekcje: imprezowa i bibliotekarska. Sekcja imprezowa zajmowała się przygotowaniem wieczorków - bajek dla dzieci z kl. I-III. Do obowiązków sekcji bibliotekarskiej należało obkładanie książek i konserwacja księgozbioru, pomoc nauczycielowibibliotekarzowi przy organizowaniu wystawek książek. „Koło Przyjaciół Książki” zakończyło swą działalność w $1965 \mathrm{r}^{54}$

W 1973 r. nastapiło połączenie dwóch szkół podstawowych nr 1 i 2 w jedna. Tak powstała Szkoła Podstawowa nr $1 \mathrm{im}$. Adama Mickiewicza w Sokółce. W związku z tym połączone zostały księgozbiory bibliotek obu tych szkół. Na dzień 31 grudnia 1994 r. księgozbiór liczył 22195 książek w tym 5296 ubytków. ${ }^{55}$

Ogólnie zbiory biblioteczne są w pewnym stopniu przestarzałe. Księgozbiór podręczny jest zaopatrzony w stopniu zadawalającym, zawiera pozycje tj.: encyklopedie, słowniki językowe i rzeczowe, poradniki encyklopedyczne, roczniki statystyczne, albumy, atlasy. Największy zakup książek pod względem ilościowym przeprowadzono w 1993 r. na sumę około 10000000 złotych (starych). ${ }^{56}$

Istotnym problemem biblioteki jest brak czytelni, gdyż szkoła ma poważne problemy lokalowe.

Od roku szkolnego 1993/94 biblioteka szkolna przygotowuje uroczyste „Pasowanie na czytelnika” dla klas I, podczas którego rozdawane są pamiątkowe dyplomy i zakładki do książek. Część artystyczna polega na przedstawieniu przez uczniów starszych klas krótkiej inscenizacji związanej z książką. ${ }^{57}$ 
Liczba czytelników waha się w granicach $100 \%$ uczniów szkoły. Od roku szkolnego 1988/89 zauważa się wzrost liczby wypożyczeń. Wyniki te osiagga się dzięki sumiennej pracy nauczycieli bibliotekarzy, którzy starają się zachęcić do czytania książek poprzez rozmowy z czytelnikami o ich zainteresowaniach, proponowanie ciekawych pozycji. Na terenie wypożyczalni wyeksponowano wolne półki w regale $\mathrm{z}$ estetycznym napisem: „To warto przeczytać”, na których ustawia się książki o różnej tematyce.

Stan czytelnictwa oraz przyrost księgozbioru ilustruje poniższa tabela nr 11. Czytelnictwo obejmuje klasy II-VIII z wyłączeniem klas I, które w pierwszym roku nauki nie korzystają samodzielnie z biblioteki. Dopiero w II półroczu nauki wychowawczynie klas biorą komplety książek i same nimi rozporządzają.

\section{Czytelnictwo uczniów w latach 1985-1994}

Tabela $\mathrm{nr} 11^{58}$

\begin{tabular}{|c|r|r|r|r|}
\hline Rok szkolny & \multicolumn{1}{|c|}{$\begin{array}{c}\text { Liczba } \\
\text { uczniów }\end{array}$} & $\begin{array}{c}\text { Liczba } \\
\text { czytelników }\end{array}$ & $\begin{array}{c}\text { Liczba } \\
\text { wypożyczeń }\end{array}$ & $\begin{array}{c}\text { Stan } \\
\text { księgozbioru }\end{array}$ \\
\hline $1984 / 85$ & 949 & 941 & 25611 & 17795 \\
\hline $1985 / 86$ & 1031 & 1031 & 13521 & 18841 \\
\hline $1986 / 87$ & 1126 & 1125 & 24724 & 19151 \\
\hline $1987 / 88$ & 646 & 644 & 8068 & 19893 \\
\hline $1988 / 89$ & 653 & 650 & 16021 & 10394 \\
\hline $1990 / 91$ & 810 & 809 & 18102 & 20920 \\
\hline $1991 / 92$ & 780 & 780 & 18347 & 21240 \\
\hline $1992 / 93$ & 807 & 804 & 19622 & 21590 \\
\hline $1993 / 94$ & 906 & 905 & 20417 & 22191 \\
\hline
\end{tabular}

\section{Liceum Ogólnokształcące im. M. Kopernika w Sokólce}

Inicjatorem i założycielem pierwszego gimnazjum w Sokółce był Piotr Ejsmont, starosta powiatowy, z zawodu pedagog. 8 września 1921 r. zostato utworzone gimnazjum Koedukacyjne Humanistyczne. Poziom nauczania był niski, pierwszą maturę w 1928 r. zdało zaledwie trzech absolwentów, dlatego w 1929 r. gimnazjum zostało zamknięte.

Od roku szkolnego 1937/38 rozpoczęło swą działalność Prywatne Gimnazjum Koedukacyjne Wacława Kołodziejskiego w Sokółce, które mieściło się w budynku starej plebanii Kościoła Rzymsko-Katolickiego. 
Po wyzwoleniu, pierwszy rok szkolny rozpoczął się w październiku 1944 r. Szkoła nosiła wówczas nazwę: Prywatne Gimnazjum Koedukacyjne Ogólnokształcące Spółdzielni Oświatowej w Białymstoku Filia nr 1 w Sokółce.

Od 1946 r. szkoła posiadała już własną bibliotekę. Z braku funduszy wprowadzono symboliczną opłatę za korzysıanie z biblioteki:

- uczeń - 1 zł miesięcznie;

- nauczyciel - 30 zł miesięcznie.

$\mathrm{Z}$ powodu trudności lokalowych w szkole nie było czytelni. Biblioteka posiadała 615 woluminów i 43 czytelników. Młodzież w ramach robót ręcznych, sama oprawiała książki. Z własnych funduszy biblioteka prenumerowała dwa czasopisma: „Płomień” i „Młodą Rzeczpospolita”. W 1948 r. księgozbiór zwiększył się do 639 woluminów, a liczba czytelników wzrosła do $57 . .^{59}$

W styczniu 1960 r. nastapiła przeprowadzka do nowego gmachu szkolnego przy ul. Mickiewicza. Dopiero w 1974 r. wygospodarowano w szkole pomieszczenie na lokalizację biblioteki i czytelni.

Dzięki centralnemu zakupowi biblioteka Liceum Ogólnokształcącego została zaopatrzona w encyklopedie, słowniki językowe i rzeczowe oraz w znaczną ilość podręczników i poradników z zakresu bibliotekarstwa, wiedzy o książce i bibliografii.

Aktualnie (1994 r.) biblioteka przy Liceum Ogólnokształcącym posiada bogaty księgozbiór w czytelni, który umożliwia uczniom rozwijać swoje zainteresowania i uzdolnienia indywidualne przez co następuje ukierunkowanie przedmiotowe. Przy liczbie uczniów 681 przez czytelnię przewija się dziennie ponad 100 osób. ${ }^{60}$

Z powodu braku wystarczających funduszy księgozbiór wypożyczalni nie jest zadawalający. Ciągle brakuje bieżących nowości ukazujących się na rynku księgarskim. Największą popularnością cieszą się opracowania lektur, bibliografie pisarzy oraz omówienia poszczególnych epok literackich.

Księgozbiór biblioteki na dzień 31 grudnia 1994 r. liczy 26804 woluminów, w tym 988 podręczników oraz 7706 ubytków. Ostatni zakup książek był w 1993 r. na sumę 26308000 starych złotych. ${ }^{61}$

Według opinii bibliotekarzy w Liceum Ogólnokształcącym czytelnictwo młodzieży nie jest zadawalające. Statystyka notuje liczbę wypożyczeń literatury popularnonaukowej. Młodzież narzeka na brak książek o tematyce dotyczącej problemów dzisiejszych nastolatków. Bardziej ich interesuje to co się dzieje teraz niż wydarzyło się wczoraj. 
Stan czytelnictwa uwarunkowany jest też liczbą uczniów w roku szkolnym, która uzależniona jest od ilości oddziałów. W roku szkolnym 1992/93 odnotowano niską liczbę wypożyczeń, spowodowaną tym, iż biblioteka nie była otwarta w pełnym wymiarze godzin.

\section{Czytelnictwo uczniów Liceum Ogólnokształcącego w Sokółce w latach 1983-1994}

Tabela nr $12^{62}$

\begin{tabular}{|c|r|r|r|r|r|r|}
\hline \multirow{2}{*}{$\begin{array}{c}\text { Rok } \\
\text { szkolny }\end{array}$} & uczniów & $\begin{array}{c}\text { czytel- } \\
\text { nilków }\end{array}$ & $\begin{array}{c}\text { wypożyczen } \\
\text { oglnie }\end{array}$ & $\begin{array}{c}\text { wypożyczeń } \\
\text { literatury } \\
\text { popularno- } \\
\text { naulkowej }\end{array}$ & $\begin{array}{c}\text { Ogólny } \\
\text { stan } \\
\text { księgo- } \\
\text { zbioru }\end{array}$ & $\begin{array}{c}\text { Liczba } \\
\text { pod- } \\
\text { ręczników }\end{array}$ \\
\hline $1984 / 85$ & 656 & 625 & 14965 & 2039 & 21274 & 427 \\
\hline $1985 / 86$ & 383 & 383 & 8550 & 1437 & 22211 & 429 \\
\hline $1986 / 87$ & 450 & 450 & 9904 & 2870 & 23160 & 484 \\
\hline $1987 / 88$ & 462 & 460 & 8517 & 4796 & 23921 & 681 \\
\hline $1988 / 89$ & 481 & 481 & 5709 & 1077 & 24874 & 709 \\
\hline $1989 / 90$ & 540 & 540 & 5413 & 1446 & 25568 & 780 \\
\hline $1990 / 91$ & 598 & 598 & 5715 & 1302 & 25729 & 800 \\
\hline $1991 / 92$ & 709 & 707 & 6417 & 1257 & 25955 & 826 \\
\hline $1992 / 93$ & 707 & 707 & 4261 & 1022 & 26230 & 871 \\
\hline $1993 / 94$ & 681 & 665 & 8205 & 1847 & 27679 & 957 \\
\hline
\end{tabular}

\section{Odrębność kulturalna społeczności sokólskiej}

\section{a) Książka w środowisku katolików sokólskich. Biblioteka i księgarnia przy parafii św. Antoniego}

Od 1949 r. funkcjonuje biblioteka parafialna przy kościele św. Antoniego. Księgozbiór liczy ponad 400 woluminów, wszystkie pozycje są o tematyce religijnej. Wierni mogą wypożyczać książki w każdą niedzielę w ciągu roku. W bibliotece znajdują się również periodyki m.in. „Obserwatore Romane" a także biuletyny ekumeniczne.

Ponadto rozprowadzane są czasopisma religijne wśród 300 abonentów, oprócz tego parafia przesyła czasopisma do szpitali sokólskich. ${ }^{63}$ 
Z książek teologicznych znajdujących się na stanie biblioteki korzystają również studenci z Akademii Teologicznej w Suwałkach oraz księża z Kurii Białostockiej.

W okresie stalinizmu biblioteka nie prowadziła swojej działalności, ale książki nie zostały skonfiskowane.

W maju i czerwcu parafia rozsyła poszczególnym wsiom w regionie sokólskim książki związane tematycznie z obchodzonymi świętami i odprawianymi nowennami, które odczytywane są fragmentami w trakcie nabożeństw.

Od pięciu lat prowadzi się społecznie sprzedaż książek o tematyce religijnej. Księgarnia parafialna dysponuje na bieżąco nowościami wydawniczymi, które są chętnie kupowane przez parafian. W grudniu 1994 r. największą populamością cieszyła się książka Jana Pawła II Przekroczyć próg nadziei. ${ }^{64}$

Od 1992 r. obserwuje się zmniejszenie zainteresowania nabywaniem książek ze względu na ich wysokie ceny jak również postępujący wzrost liczby bezrobotnych w regionie sokólskim.

Parafia zajmuje się rozprowadzaniem książek o tematyce antyalkoholowej wśród wiernych, którzy składają okresowe przyrzeczenia nie picia alkoholu.

Ponadto parafia posiada kilka pozycji książek XIX wieku oraz Zbiór kopii wybranych dokumentów historycznych parafii sokólskiej (XVI-XIX wiek) autorstwa ks. dziekana mgr Tadeusza Kalinowskiego.

\section{Sokólski bibliofil i miłośnik książek - mecenas Dominik Donat Pietrasz (1892-1981)}

Region sokólski może poszczycić się człowiekiem, którego największym hobby było zbieranie książek. Tą osobą był Dominik Donat Pietrasz urodzony I sierpnia 1892 r. w Kuryłach koło Sokółki, syn Feliksa Pietrasza i Ludwiki z Ignatowiczów. Rodzice zajmowali się gospodarstwem rolnym. Dominik D. Pietrasz był czwartym z sześciu synów. Rodzice zmarli wcześnie. Chłopcy wychowywali się sami i wszyscy zdołali ukończyć szkołę podstawową - co w tych warunkach nie było łatwe. Dominik D. Pietrasz ukończył Miejską Szkołę w Sokółce ${ }^{65}$ dnia 7 czerwca 1907 r. Następnie rozpoczął pracę w Kuźnicy jako sekretarz u Piotra Aleksandrowicza Follendorfa - Naczelnika Ziemskiego. Tam nabywał pierwszego doświadczenia prawniczego. Po odzyskaniu przez Polskę niepodległości, 7 lipca 1920 r. został zaliczony w poczet obrońców przy Sądzie Okręgowym w Białymstoku. 
Będąc już mecenasem rozpoczął pracę w sądzie sokólskim w charakterze obrońcy. W 1940 r. uciekł przed bolszewikami do Grójca pod Warszawa. Aresztowany 4 sierpnia 1944 r. przez gestapo trafił do obozu w Essen. Uwolniony 3 maja 1945 r. osiadł w Pułtusku i podjął pracę w sądzie jako obrońca. W 1947 r. powrócił do Sokółki, gdzie z trudem odzyskał mieszkanie w swoim domu przy ul. Kościelnej ${ }^{67}$, który został objęty kwaterunkiem. 30 września 1951 r. ma mocy uchwały Rady Adwokackiej w Białymstoku został wpisany na listę adwokacka. Zmarł w kwietniu 1981 r w wieku 91 lat.

Przez całe źycie związany z Ziemią Sokólską - był jej wielkim miłośnikiem i znawcą. Potrafił bardzo ciekawie opowiadać o jej historii i walorach przyrodniczych. Był zapalonym bibliofilem. Z okresu przedwojennego zachowało się niestety niewiele pozycji. W swoim księgozbiorze liczącym około 5000 tomów - oprócz słowników, encyklopedii, albumów zbierał książki z zakresu geografii, biologii i historii.

Historia Ziemi Sokólskiej stała się prawdziwą pasją D.D. Pietrasza u schyłku jego życia. Jeździł po kraju, zbierał materiały. Korespondował m.in. z Biblioteką Jagiellońską, Biblioteką Narodową, Biblioteką Polskiej Akademii Nauk i innymi bibliotekami uniwersyteckimi. Zbierał materiały w celu napisania monografii Ziemi Sokólskiej. Niestety nie zdążył tego dokonać. Pod koniec swojego życia uczynił gest w kierunku mieszkańców Sokółki, chciał swój dom wraz z księgozbiorem przekazać miastu w zamian za utworzenie w tym miejscu biblioteki publicznej jego imienia. ${ }^{68}$

Nie było to możliwe, gdyż w owym czasie panował inny klimat polityczny, a niektórzy członkowie rodziny Pietraszów byli notowani w kartotekach Urzędu Bezpieczeństwa (UB). ${ }^{69}$

Cały księgozbiór mecenasa Dominika Donata Pietrasza trafił w ręce pozostałej rodziny, $\mathrm{i}$ w tej chwili jest nadal powiększany, a materiały do opracowań historycznych na temat Ziemi Sokólskiej powoli są segregowane i czekają na opracowanie. ${ }^{70}$

\section{b) Obcowanie z książką wśród ludności prawosławnej}

Wierni z parafii św. Mikołaja w zależności od potrzeb korzystają z prywatnych zbiorów księży prawosławnych. ${ }^{71}$

Od 1993 r. funkcjonuje w Białymstoku drukarnia „Orth druk”, która zajmuje się realizowaniem zamówień parafii cerkiewnych z okolic. Dzięki temu powstała biblioteczka klasyków literatury rosyjskiej: Włodzimierz S. Makanin, Fiodor M. Dostojewski, Antoni P. Czechow, Aleksiej N. Tołstoj. 
Ludność prawosławna nie ma rozwiniętej potrzeby obcowania $\mathrm{z}$ literaturą religijna. ${ }^{72}$

Do najstarszych książek znajdujących się w prywatnej biblioteczce na plebanii cerkiewnej można zaliczyć: „Katechezy św. Cyryla arcybiskupa Jerozolimy”, Moskwa 1824 r; „Służebnik”, Moskwa 1747 - książka do nabożeństw zawierająca teksty ewangelii na cały rok.

\section{c) Żydowska kultura regionalna}

Żydowskie organizacje społeczno-kulturalne od zarania przywróconej do istnienia państwowości polskiej rozpoczęły energiczną walkę $z$ analfabetyzmem poprzez przyswajanie wiedzy o Polsce. W każdym większym miasteczku polskim istniała biblioteka żydowska.

W Białymstoku działa duża i zasobna prywatna Biblioteka im. Szolema Alejchema. ${ }^{73}$ Pierwsza żydowska biblioteka powstała w Białymstoku w 1907 r. W 1910 r. organizacja „Jugend Farejn” uruchomiła bibliotekę i czytelnię, która przekształciła się w Bibliotekę Alejchema. Biblioteka została otwarta 13 marca 1919 r. w trzecią rocznicę śmierci Szolema Alejchema.

Od 1919 r. pełniła rolę biblioteki miejskiej, posiadając w swym księgozbiorze początkowo 4000 woluminów wchłaniając zbiory Natana Głogowskiego (800 woluminów), prezesa Rady Bibliotecznej Ryflinda, Gminy Żydowskiej (przy. ul. Sosnowej Towarzystwa „Tarbut”, księgozbiory szkolne oraz biblioteki prywatne liczyły w 1927 r. już około 28000 tomów). Wieloletnim jej kierownikiem był nauczyciel i dziennikarz Chaim Lewiński.

Rosnące zapotrzebowanie na książkę polską wśród ludności żydowskiej, zainteresowanie dla polskiej kultury, historii i literatury oraz rządowe subwencje dla biblioteki przyczyniły się do otwarcia w $1921 \mathrm{r}$. dziahu literatury polskiej.

W 1934 r. księgozbiór Biblioteki Szolema Alejchema liczył 44.000 woluminów. Dla porównania: Biblioteka Miejska w Białymstoku liczyła w 1985 r. 220.000 woluminów (bez filii bibliotecznych). Nie było to mało zważywszy iż Białystok posiadał jeszcze kilka innych bibliotek żydowskich oraz księgozbiory ksiąg religijnych w synagodze.

Prócz biblioteki Alejchema w mieście funkcjonowały: Biblioteka Literatów i Dziennikarzy Żydowskich, która prenumerowała 90 tytułów czasopism, Biblioteka Gimnazjum Hebrajskiego, Biblioteka Bractwa Linas Hacedek oraz inne biblioteczki, które znajdowały się przy każdej z prywatnych szkół żydowskich. ${ }^{74}$ 
Wiarygodność faktu istnienia Biblioteki im. Szolema Alejchema przedstawia list Abrahama Vereda byłego mieszkańca Białegostoku: "(...) tak więc moge objaśnić jak było w Biatymstoku, a więc byta to duża biblioteka żydowska, nazywała się „, Miejska żydowska biblioteka imieniem Szolema Alejchema. Byt to wybitny żydowski pisarz. W bibliotece byty wszystkie wydania w języku żydowskim i polskim: utwory literackie, powieściowe, dzieta naukowe, klasyka, muzyczne, utwory epickie, poetyczne itd. oraz utwory przektadane z innych języków. To byla bardzo bogata biblioteka i naprawdę między abonentami byli też Polacy, można powiedzieć, że ta biblioteka stużyta catej ludności miasta.

Ja też bylem abonentem, cała nasza rodzina brała tam ksiązki, a to kosztowato (jeden) l zloty miesięcznie.

Ta biblioteka widocznie byla spoteczna i kierowana przez komitet wybrany. Ta biblioteka byta na ulicy Sienkiewicza (nie pamiętam numeru) $w$ trzy piętrowym budynku. Miała taż salę, gdzie ludzie mogli czytać tzn. czytelnia, jako uczeń mogłem tam nawet zrobić lekcje. Mam nadzieje, że moja pomoc byta skuteczna."75

Sokółka również mogła się poszczycić istnieniem bibliotek żydowskich. Dowiadujemy się o tym z informacji Szmuela Bunima, który przethumaczył na język polski fragment książki napisanej w języku jidysz pt. „Sokółka - Encyklopedia Galujst”, Izrael 1968, s. 319-320.

„Biblioteka w naszym mieście. Pierwsza wypożyczalnia ksiqżek byla w sklepie Mojżesza Sztajna. W roku 1902-1903 sklep znajdowal sie w domu Jakuba Blumentafa - dziadek Chaji Szmul. Po pewnym czasie biblioteka przeszła do sklepu Nachmana Saja Lajbesa. Sklep zostat podzielony na dwie części. Jedna zapetniona zostata ksiażkami, druga materiałami budowlanymi".

Kiedy znów zaistniały trudności, działacze społeczni z ramienia „Bundu” wzięli bibliotekę pod swoją opiekę. Po wybuchu pierwszej wojny światowej biblioteka została zamknięta. Ale podczas okupacji niemieckiej wznowione zostały dążenia do życia kulturalnego. Dwie nowe biblioteki zostały otwarte. Jedna z inicjatywy „Bundu” w prywatnym domu Elianima Rabinowicza, a druga z inicjatywy Kół Syjonistycznych pod kierownictwem Lipsera, Kowalskiego, Berkowskiego i innych. Toczyły się zmagania o wpływ na bibliotekę.

W owych latach okupacji niemieckiej, życie społeczne było burzliwe. Wpływy myśli syjonistycznej były bardzo silne, w końcu ogarnęły większą część ludności żydowskiej. Dwie biblioteki zjednoczyły się pod wspólnym zarządem. 
Organizowano w tym czasie wieczorne kursy prowadzone przez Berkowskiego i Grischojsa, byłych uczniów szkoły hebrajskiej. Pod ich wpływem książki hebrajskie były bardzo pożądane.

Po nie kończących się zmaganiach Syjoniści osiągnęli większość i objęli kierownictwo biblioteki" ${ }^{76}$

Poza tym Szmuel Bunim przytacza pewną anegdotę, którą opowiadała mu matka (urodzona w 1894 r., opuściła Sokółkę w 1921 r.): „Kiedy otwarta zostala bibliotekaw Sokótce, byla atrakcjq dla calej młodzieży żydowskiej. Ale faktem bylo, że w tym czasie bylo bardzo wielu, którzy w ogóle nie umieli czytać. Młoda dziewczyna zapytana jaka ksiqżkę sobie życzy, wzięła jedna $z$ najblizszej pólki, twierdzqc, że wlaśnie tę chce czytać. To byla „, Gramatyka - Kripicznikowa”. Po tygodniu zwrócila ksiażkę. No jak, ciekawa, pytali ja? Nic specjalnego - odpowiedziala. Romans, jak wszystkie romanse. Gramatnikow powiesit się, Kripicznikow zastrzelit się, a bohaterka ksiażki wyszla za trzeciego". 77

O tym jak funkcjonowały biblioteki żydowskie w Sokółce przed II wojną światową mówią byli mieszkańcy tego miasta, którzy wyemigrowali do Izraela: Efraim Ben-Zeer, adwokat Nissan Tykociński oraz Moshe Verbin.

Według ich relacji w Sokółce były przed wojną dwie biblioteki żydowskie. Jedna w języku żydowskim a druga w języku hebrajskim. Biblioteka w jęz. żydowskim była prowadzona przez Żydowskie Towarzystwo Kulturalne: „Idisze Kultur Gezełszaft” i było w niej około 10.000 książek w języku żydowskim. Większość zbiorów stanowiły oryginały z klasyki żydowskiej m.in. Szaloma Alejchema, Ischaka Lejb Perec ${ }^{78} \mathrm{i}$ innych.

Znajdowały się też różne thumaczenia $\mathrm{z}$ innych języków. Biblioteka była prowadzona przez ochotników i była czynna trzy razy w tygodniu w godzinach wieczornych. Większość ludności żydowskiej w Sokółce była abonentami tej biblioteki. Oprócz tego Żydowskie Towarzystwo Kulturalne prowadziło także kółko przy bibliotece i od czasu do czasu były przedstawienia w Domu Ludowym. Żydowskie Towarzystwo Kulturalne mieściło się na ulicy Białostockiej.

Biblioteka hebrajska była prowadzona przy szkole „Tarbut" (po hebrajsku: Kultura) i miała niewiele książek oraz przy religijnej szkole „Talmud-Toze” (Nauka Testamentu). Biblioteki te miały mało abonentów. Szkoły i biblioteki znajdowały się na placu koło Wielkiej Synagogi (która została rozebrana do ostatniej cegiełki, tak jak wszystkie inne synagogi i bożnice w Sokółce). W każdej synagodze były książki „Talmudyczne”, służące do uczenia się Talmuda przez modlących się tam Żydów. ${ }^{79}$ 
Na podstawie tych wszystkich relacji można stwierdzić, że społeczność żydowska miała znaczący udział w kulturalnym życiu Polski przedwojennej.

\section{d) Trzysta lat osadnictwa tatarskiego}

\section{Rękopiśmienna literatura religijna jako forma twórczości ludowej}

Początki osadnictwa tatarskiego obejmującego północno-wschodnie tereny obecnego województwa białostockiego sięgają II połowy XVII wieku, które miało bezpośredni związek z wojnami polsko-tureckimi.

Tatarom polskim przyznano prawa równające ich ze szlachtą chrześcijańską, a później nadano nobilitacje i umożliwiono zachowanie wiary przodków.

W niejednej rodzinie tatarskiej, poczesne miejsce wśród rodzinnych pamiątek, zajmowały rękopiśmienne księgi religijne. Oprawione w skórę lub tekturę, leżały na półkach domowych bibliotek, albo pozostawały ukryte $w$ jakimś domowym zakamarku. Pisane były wyłącznie alfabetem arabskim, choć zawierały w sobie, obok tekstów czysto arabskich, także polskie i białoruskie. Po rękopisy nikt nie sięgał zanim nie umył rak, nie dawano też nikomu obcemu, chyba że był to współplemieniec znający alfabet arabski.

Niekiedy tłumaczeniami tych rękopisów zajmowali się orientaliści i alwiści, ale Tatarzy bardzo niechętnie je wypożyczali. Tylko kilka rodzin zdecydowało się przekazać je do kilku większych bibliotek w kraju i do Muzeum Ziemi Sokolskiej w Sokółce. ${ }^{80}$

Najważniejszą z ksiag religijnych muzułmanów polskich był „Koran”, przepisywany wiele razy z dawniejszych kopii, które powstały ongiś w oparciu o nieistniejący już oryginał.

Wśród eksponowanych Koranów w Muzeum Ziemi Sokólskiej w Sokółce, znajdują się egzemplarze drukowane w połowie XIX wieku, a także rękopisy, których okładki, chroniące przed zniszczeniem, owijano w białe lniane płótno. Inne z prezentowanych rękopisów to „muhiry”. Są to wersety Koranu kaligraficznie wypisane lub wyszyte na tkaninie.

W ekspozycji jest też do obejrzenia plansza zawierająca modlitwy i formuły religijne, która została wykonana w drukarni uniwersyteckiej w Kazaniu w 1870 r. Teksty zostały wydrukowane czcionką arabską w języku arabskim i tatarskim. 
Innym okazem literatury rękopiśmiennej Tatarów jest „Tasfir” wymawiany najczęściej przez nich jako „Tesfir” lub „Tapsir”. Zawierał objaśnienia tekstów koranicznych i służył głównie do nauki religii.

Do najstarszych rękopisów tatarskich w Polsce należy „Kitab” z 1792 r., powstały dzięki wytrawnemu kopiście Jusufowi Heljesewiczowi, a znajdujący się w Kruszynianach. „Kitab” (po arabsku książka) o dość różnorodnej treści, zajmuje szczególne miejsce w literaturze tatarskiej. Znajdują się w nim opowiadania z życia Muhammada i innych Proroków, objaśnienia niektórych obrządków religijnych, tłumaczenia modlitw na język polsko-białoruski. W regionie sokólskim jeszcze w latach pięćdziesiątych, podczas spotkań bajramowych, odczytywano dłuższe fragmenty. ${ }^{81}$ W mieszkaniu właściciela „Kitabu” zbierało się grono krewnych, przyjaciół. Właściciela rękopiśmiennego zabytku otaczano powszechnym szacunkiem i do niego udawało się po rady w sprawach wiary. Nie dotrwał do naszych dni zwyczaj zbiorowego słuchania tej księgi. „Kitaby” oddziaływały na całe pokolenia: szerzyły umiłowanie tradycji, kształtowały światopoglądy. ${ }^{82}$

Do najbardziej rozpowszechnionych rękopisów znajdujących się w Muzeum Ziemi Sokolskiej należą ,chamaiły”, które były przepisywane przez różnych kopistów w ciagu stuleci. Ich bogato zdobione skórzane okładki świadczą o kontaktach i naśladownictwie orientalnych wzorów. Zawierają one modlitwy na różne okazje, opisy wszystkich obrzędów religijnych, teksty amuletów, formuły magiczne, tablice cyfr szczęśliwych, a czasem mały słowniczek terminów religijnych. Komentarz i tłumaczenie tekstów arabskich, tatarskich i turecko-tatarskich napisane jest po białorusku i po polsku literami arabskimi. ${ }^{83} \mathrm{~W}$ okresie zaborów kiedy zabroniono używania języka polskiego, Tatarzy stosowali arabskie litery do napisania polskich tekstów na kamieniach nagrobnych. „Chamaiły” są nadal we wszechstronnym użyciu u Tatarów $\mathrm{z}$ regionu sokólskiego. ${ }^{84}$

„Daławary” są to długie papierowe zwoje zawierające arabskie teksty religijne. Przechowywano je w kopercie z tkaniny. Małe dzieci nosiły je jako amulety chroniące przed nieszczęściem, a dorośli posługiwali się takimi modlitewnikami w czasie podróży i w trakcie wypraw wojennych. Niektóre formy „daławarów”, a wśród nich egzemplarze pisane atramentem sporządzonym z szafranu, były wkładane zmarłemu do grobu. ${ }^{85}$

Przepisywaniem ksiag liturgicznych, ze starych rękopisów zajmowali się w przeszłości duchowni muzułmańscy, a także ludzie $w$ podeszłym wieku, wyłącznie mężczyźni. Kopiści tatarscy tworzyli swe rękopisy w długie jesienno-zimowe wieczory. Używali gęsiego pióra tzw. „kolemu” 
lub zwykłej stalówki. Do pisania służył atrament własnego wyrobu o czarnym lub czerwonym kolorze. Sztukę pisania niejako uświęcano, była to oryginalna twórczość wynikająca z potrzeby utrzymania tradycji.

Każdy z kopistów, na ostatniej przepisanej stronie nowej księgi, umieszczał zwykle swoje nazwisko oraz datę rozpoczęcia i zakończenia tej żmudnej pracy. Księgi te nabierały przez to swoistych cech lokalnych.

Sztuka kopiowania ksiagg liturgicznych zaczęła zamierać po $1945 \mathrm{r}^{86}$ Kopistów można było spotkać tylko na Białostocczyźnie. Do znanych kopistów należał Stefan Jasiński, immam gminy kruszyniańskiej w regionie sokólskim. Pisał przede wszystkim podręczniki do nauki religii i prowadził punkt katechetyczny dla dzieci tatarskich w Sokółce. ${ }^{87}$

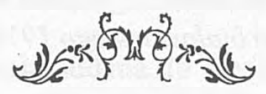

Przypisy:

'Patrz: kompilacyjna Kronika polska - źródto inspiracji pisarzy romantycznych.

${ }^{2}$ Przywilej ten znajduje się w Archiwum Państwowym w Wilnie, odpis zaś w aktach miasta Archiwum Wojewódzkiego w Białymstoku.

${ }^{3}$ Kraśko R.: Oświata. Nauka. Kuliura. [W:] Bialostockie, Warszawa 1969.

${ }^{4}$ Tamże.

${ }^{5}$ Daszuta L.: Rola biblioteki publicznej w realizacji polityki kulturalnej państwa na przykladzie dzialalności Miejskiej Biblioteki Publicznej w Sokólce (maszynopis).

${ }^{6}$ Tamże.

7 Tamże.

${ }^{8}$ Tamże.

${ }^{9}$ Realizacji tych zamierzeń przeszkodził wybuch II wojny światowej.

${ }^{10}$ Karlikowski J.: Polityka okupacyjna III Rzeszy w okręgu bialostockim (1941-1944), Białystok 1960 r., s. 43.

"Daszuta L.: op. cit.

${ }^{12}$ Kozioł Cz.: Polityka biblioteczna, Warszawa 1962, s. 19-20.

${ }^{13}$ Ustawa z 25 września 1954 r. o reformie podziału administracyjnego i powolaniu gromadzkich rad narodowych, [W:] Dziennik Urzędowy Nr 43 pozycja 191.

${ }^{14}$ Kronika Biblioteki Publicznej Miasta i Gminy w Sokólce, Cz. I.

${ }^{15}$ Daszuta L.: op. cit.

${ }^{16}$ Tamże.

${ }^{17}$ Tamże.

${ }^{18}$ Kronika Biblioreki.

${ }^{19}$ Materiały Biblioteki Publicznej Miasta i Gminy w Sokółce: sprawozdanie opisowe, informacje oraz sprawozdania dla GUS (skoroszyt).

${ }^{20}$ Sprawozdanie biblioteki powiatowej za rok 1948, BPMiG w Sokółce. 
${ }^{21}$ Materiały BPMiG w Sokółce: sprawozdanie opisowe, informacje oraz sprawozdanie dla GUS (skoroszyt).

${ }^{22}$ Kronika BPMiG w Sokólce, Cz. 3.

${ }^{23}$ Materiały BPMiG w Sokółce: sprawozdanie opisowe, informacje oraz sprawozdanie dla GUS (skoroszyt).

${ }^{24}$ Kronika BPMiG w Sokólce, Cz. 3.

${ }^{25}$ Tamże.

${ }^{26}$ Tamże.

${ }^{27}$ Sokółka liczyła w 1947 r. około 5000 mieszkańców, zaś wsie w powiecie sokolskim zamieszkiwało około 88000 ludności. Dane według Urzędu Statystycznego w Sokółce.

${ }^{28}$ Dane według sprawozdań BPMiG w Sokółce dla Głównego Urzędu Statystycznego w Białymstoku z lat 1957-1974.

${ }^{29}$ W 1973 r. nastapił spadek wypożyczeń i czytelników w PiMBP w Sokólce z powodu zamknięcia wypożyczalni dla dorosłych na okres 6 miesięcy ze względu na remont pomieszczen.

${ }^{30}$ Sprawozdanie opisowe z obsady kadrowej w poszczególnych punktach bibliotecznych podlegających PiMBP w Sokółce na dzień 31 grudnia 1957 roku.

${ }^{31}$ Rocznik statystyczny wojewódzrwa bialostockiego 1974. Wojewódzki Urząd Statystyczny, Białystok 1975.

${ }^{32}$ Rocznik statystyczny województwa bialostockiego 1994; Wojewódzki Urząd Statystyczny, Białystok 1995.

${ }^{33}$ Filie biblioteczne znajdujące się w gminach: Nowy Dwór, Sidra, Dąbrowa Białostocka, Kuźnica Białostocka, zostaly przejęte w 1990 r. przez tamtejsze samorządy terytorialne w poszczególnych gminach.

${ }^{34}$ Rocznik statystyczny województwa bialostockiego 1994. Op. cit.

${ }^{35}$ Sprawozdanie opisowe z działalności BPMiG w Sokółce za rok 1992 dla GUS w Warszawie.

${ }^{36}$ Sprawozdanie z dzialalności oświatowej BPMiG w Sokólce za rok 1971, Sokółka 1972.

${ }^{37}$ Tamże.

${ }^{38}$ Kronika BPMiG w Sokólce; Cz. 2.

${ }^{39}$ Tamże.

${ }^{40}$ Kronika Oddzialu Dziecięcego w BPMiG w Sokólce, Cz. I.

${ }^{41}$ Sprawozdanie z działalności kulturalno-oświatowej Oddziału dla Dzieci BPMiG w Sokólce za rok 1979.

${ }^{42}$ Kronika Oddzialu dla Dzieci w BPMiG w Sokólce; Cz. 3 i 4: pamiątkowe wpisy wychowawczyń przedszkolaków wyrażających podziękowanie za miłe przyjęcie w bibliotece.

${ }^{43}$ Sprawozdanie z działalności kulturalno-oświatowej Oddziału dla Dzieci BPMiG w Sokółce dla WUS w Białymstoku za lata 1991-1994.

${ }^{44}$ Dane według sprawozdań Oddziału dla Dzieci w Sokółce dla BPMiG w Sokółce za lata 1983-1994.

${ }^{45} \mathrm{~W}$ sesji wzięli udział nauczyciele bibliotekarze szkół średnich i podstawowych z gminy Sokółka.

${ }^{46}$ Pozycje z zakresu pedagogiki i psychologii.

${ }^{47}$ Sprawozdanie opisowe z działalności Pedagogicznej Biblioteki Wojewódzki im. Wł. Spasowskiego w Białymstoku Filia w Sokółce za rok 1994. 
${ }^{48}$ Tamże.

${ }^{49}$ Biuletyny $\mathrm{z}$ konspektami lekcyjnymi z języka polskiego dla klas IV-VIII i nauczania początkowego.

${ }^{50}$ Księgozbiór biblioteki został wzbogacony przez dar 29 książek byłego inspektora oświaty mgr Józefa Zalewskiego. Największą wartość przedstawia Historia wychowania S. Kotta z $1924 \mathrm{r}$.

${ }^{51}$ Dane wg. sprawozdań opisowych Biblioteki Pedagogicznej w Sokółce z lat 1985-1994 dla Pedagogicznej Biblioteki Wojewódzkiej im. Wł. Spasowskiego w Białymstoku.

${ }^{52}$ Tamże.

${ }^{53}$ Zieniuk J.: Zatożenia organizacyjno-programowe Rejonowych Zespotów Doskonalenia Nauczycieli w województwie bialostockim [W:] Bialostocki Biuletyn Oświatowy; Białystok $1993 \mathrm{nr} 6$, s. 4.

${ }^{54}$ Kronika Szkoly Podstawowej nr l w Sokólce, Cz. 2.

${ }^{55}$ Księga inwentarzowa oraz Księga ubytków biblioteki szkolnej SP. nr l w Sokótce.

${ }^{56}$ Dowód zakupu książek z dnia 10 grudnia 1993 r. (teczka: Dowody wpływu-rachunki)

${ }^{57}$ Dziennik biblioteki szkolnej w SP. nr l w Sokólce z roku szkolnego 1993/94 i 1994/95.

${ }^{58}$ Dziennik biblioteki szkolnej w SP. nr l w Sokólce za lata 1984-1994 (stan czytelnictwa zestawienia roczne).

${ }^{59} \mathrm{~W}$ roku szkolnym 1987/88 została oddana do użytku nowa Szkoła Podstawowa nr 4, dlatego zmniejszyła się liczba dzieci SP. nr l w Sokółce.

${ }^{61}$ Chamiuk F: 40-lecie Liceum Ogólnokształcącego im. Mikolaja Kopernika w Sokółce, Białystok 1987.

${ }^{60}$ Zeszyt odwiedzin w czytelni biblioteki w Liceum Ogólnokształcącym w Sokółce za rok szkolny 1993/94 i 1994/95.

${ }^{61}$ Księga inwentarzowa, Księga ubytków oraz Księga inwentarzowa podręczników - biblioteki w Liceum Ogólnokształcącym w Sokólce.

${ }^{62}$ Dziennik biblioteki szkolnej w Liceum Ogólnoksztalcacym w Sokótce za lata 1983-1994 (Stan czytelnictwa-zestawienie roczne). Księgi inwentarzowe, Księga inwentarzowa podręczników.

${ }^{63}$ Wywiad przeprowadzono przez autorkę z ks. dziekanem mgr Tadeuszm Kalinowskim z parafii pod wezwaniem św. Antoniego w Sokółce w grudniu 1994 r.

${ }^{64} \mathrm{Na}$ podstawie rozmowy przeprowadzonej w styczniu 1995 r. z osobami zajmującymi się społecznie prowadzeniem księgami parafialnej.

${ }^{65} \mathrm{~W}$ okresie zaboru rosyjskiego szkola nosiła nazwę: Sokolskoje Gorodzkoje Uczyliszcze.

${ }^{66}$ Miejscowość w woj. białostockim nad Łosośną z siedzibą urzędu gminy. Znajduje się tu przejście graniczne na międzynarodowej linii kolejowej Warszawa-Wilno-Sankt Petersburg.

${ }^{67}$ Dawniejsza ul. Kościelna nosi teraz nazwę: ul. Ściegiennego.

${ }^{68}$ Po zakończeniu II wojny światowej willa D.D. Pietrasza została objęta kwaterunkiem, ale nie pozbawiono go prawa własności do tego domu, gdyż miał za mały metraż. Mecenas mógł zajmować część domu.

${ }^{69}$ Rodzina Pietraszów notowana była w kartotekach UB z powodu działalności w Armii Krajowej w okresie wojennym.

${ }^{70}$ Wywiad przeprowadzony przez autorkę z Iwoną Wiśniewską - przybraną córką D.D. Pietrasza 14 lutego 1995 r. w Sokółce. 
$\overline{\text { Jak duży jest księgozbiór prawosławnych nie zdołano ustalić wskutek niemożności }}$ zobaczenia go oraz braku udzielenia dokładnej odpowiedzi ze strony ks. prawosławnego.

${ }^{72} \mathrm{Na}$ podstawie opinii ks. prawosławnego z parafii św. Mikołaja.

${ }^{73}$ Szolem Alejchem - właściwie Szalom Rabinowicz żył w latach 1859-1916. Był pisarzem żydowskim, który tworzył w języku jidysz. Pisał powieści, nowele i sztuki teatralne z życia Żydów Europy np. Dzieje Tewji Mleczarza.

${ }^{74}$ List Tomasza Wiśniewskiego - redaktora Kuriera Porannego w Białymstoku do autorki niniejszej pracy, 16 lutego $1995 \mathrm{r}$.

${ }^{75}$ List Abrahama Vereda z Ramot-Menashe z lzraela do autorki, 5 marca 1995 r.

${ }^{76}$ List Shmuela Bunima z Kibbutzu Mishmar Homeger z Izraela do autorki, 28 marca $1995 \mathrm{r}$.

77 Tamże.

${ }^{78}$ Porec Icchak Lejb żył w latach 1852-1915. Był pisarzem żydowskim, klasykiem literatury jidysz w Polsce, wprowadził do niej treści społeczne. Pisał poezje, nowele (Kpiarz) oraz sztuki teatralne.

${ }^{79}$ Materiał został opracowany na podstawie listów:

- list Efraim Ben-Zeer z Ramat-Gan z Izraela do autorki niniejszej pracy, 27 marca 1995;

- list adwokata Nissana Tykocińskiego z Peth-Tigva z Izraela do autorki, 7 kwietnia $1995 \mathrm{r}$;

- list Moshe Verbina z Kibbutz Yakum z Izraela do autorki, 26 marca 1995 r.

${ }^{80}$ Miśkiewicz A.: Tatarska legenda. Białystok 1993, s. 59.

${ }^{81}$ Do jednych z trwalszych elementów przyczyniających się do integracji Tatarów polskich należały obchodzone wspólnie przez nich święta muzułmańskie. Stanowiły one okazję do zacieśnienia więzów rodzinnych.

${ }^{82}$ Patrz: przypis nr 25.

${ }^{83}$ Alfabet języka arabskiego posiada 28 znaków, natomiast alfabet języka tatarskiego 34 znaki.

${ }^{84}$ Konopacki M.: Pod bialostockimi minaretami. Białystok 1972.

${ }^{85}$ Majda T.: Jaki charakter ma piśmiennictwo Tatarów polsko-litewskich (maszynopis).

${ }^{86}$ Miśkiewicz A: Tatarska legenda. Białystok 1993, s. 60-61.

${ }^{87}$ Imam Stefan Jasiński ze względu na podeszły wiek nie zajmuje się już kopiowaniem ksiag i nauczaniem dzieci. 